\title{
Retrenchment and restructuring in an age of austerity: what (if anything) can be learned from the affluent democracies?
}

\author{
Retração e reestruturação em era de austeridade: \\ será que se pode aprender alguma coisa \\ com as democracias afluentes?
}

Paul Pierson 1

\footnotetext{
1 Center for European Studies, Harvard University. 27 Kirkland St. at Cabot Way, Cambridge, MA 02138, U.S.A. pierson@fas.harvard.edu
}

\begin{abstract}
The article discusses some difficulties of drawing implications from welfare state reform in the Organisation for Economic Co-operation and Development for "middle-income countries", and whose welfare states have been less well institutionalized. It is argued that globalization's role in contemporary social policy dynamics were not unimportant, but social processes occurring within national contexts were probably more important. There is not a single "new politics of the welfare state" but distinct political dynamics in different "regimes" or "configurations", which are characterized by different problem loads and different structures of political opportunity. Different factors are crucial in explaining outcomes in different configurations and there is little reason to expect much convergence in social policy outcomes across regime type. Contemporary welfare state reform is depicted as a process of restructuring rather than dismantling, what can encourage the possibilities for developing coalitions advancing multi-dimensional agendas of welfare state reform.
\end{abstract}

Key words Social Welfare; Globalization; Public Policy

Resumo O artigo discute algumas dificuldades em fazer analogias entre as reformas do welfare state nos países da Organisation for Economic Co-operation and Development, para os "países de renda média", cujos sistemas de proteção social são menos institucionalizados. A globalização possui um papel na dinâmica da política social contemporânea, mas processos sociais ocorrendo dentro dos contextos nacionais foram provavelmente mais importantes para as configurações que a reforma assumiu. Não existe uma única "nova política do welfare state", mas distintas dinâmicas políticas em diferentes configurações ou "regimes", os quais se caracterizam por diferentes problemas e estruturas de oportunidades politicas. Diferentes fatores explicam os resultados em diferentes configurações, as quais tampouco produzem grande convergência quanto aos resultados de suas políticas sociais. A reforma atual do welfare state é pensada como um processo de reestruturação, e não de desmantelamento, o que encoraja a possibilidade de se pensar em coalizões para se estabelecer agendas multi-dimensionais de reformas de proteção social.

Palavras-chave Bem-Estar Social; Globalização; Política Social 
As a political scientist who has concentrated on the study of social policy in the affluent democracies of the OECD (Organisation for Economic Co-operation and Development), I write with some hesitancy about the prospects for social policy development in Latin America. Because the topic is outside my area of expertise, the purposes of the current essay are modest and exploratory. I first summarize recent research conducted by myself and a team of colleagues on welfare state reform in the OECD. I then discuss the difficulties of drawing implications from this set of experiences for countries which are democratic but less affluent, and whose welfare states have been less well institutionalized. Finally, following those caveats, I nonetheless suggest that there may be some useful lessons to draw from this broad set of comparisons.

To provide at least a preliminary defense of this inquiry, it is useful to ask how plausible it is to examine the experience of the "affluent democracies" for the purpose of illuminating the circumstances facing middle-income countries. I will argue later that this is a task that must be approached with great caution. At a minimum, however, such an examination may help us to exercise our imagination in thinking about the range of possibilities for social policy in the contemporary period. In particular, I will argue that there is considerable reason for skepticism concerning the sweeping claims that have been made with respect to the consequences of globalization. Moreover, exploring the experiences of affluent democracies can highlight dimensions of the reform process that are likely to be relevant to the challenges facing middle-income countries, even if we should reasonably expect that these processes may play out quite differently given the important differences in social context.

\section{The new politics of the welfare state}

Let me begin by summarizing the main findings of our collaborative project. We focused on two central questions: what is happening to the mature welfare states of affluent democracies? And how can we account for cross-national patterns of reform outcomes? These questions were motivated by our general sense that much discussion had exaggerated the extent to which the extensive welfare states of these countries were proving to be vulnerable to radical retrenchment efforts. In particular, most of us were skeptical of the often expansive claims made about the implications of globalization.
While we recognized that there were important changes taking place in the global economy, we doubted that their impact on the welfare state was as severe as sometimes suggested. At the same time, we thought that the intensive focus on changes in the global economy distracted attention from important domestic shifts that were arguably more important for the fate of the welfare state.

Three core conclusions emerged from this study, all of which were related to a central theme. That theme was that current systems of social provision needed to be understood as the results of very long-term processes of welfare state development in these countries. Current politics plays out in a context profoundly shaped by a fifty to one-hundred year long process of expansion and institutionalization.

The first conclusion was that globalization's role in contemporary social policy dynamics had indeed been greatly exaggerated. Changes in the global economy were not unimportant, but social processes occurring within the affluent democracies were probably more important. These changes include the radical shift in employment from manufacturing to services, the demographic revolution of population aging, fundamental changes in household structures and gender relations, and the accumulation of fiscal burdens associated with previous social policy commitments. The current climate, which I term one of permanent austerity, reflects these pressures more than it does changes in the global economy. If one asks the simple counterfactual, "what would the circumstances facing these welfare states look like if the global economy had not changed in the past twenty-five years?" my view is that in fact the basic sense that there was a need for serious restructuring and cost containment would remain unchanged. The point is not that welfare states do not face acute pressures; they do. But these pressures are misspecified by accounts that emphasize the impact of globalization, they are more diverse, and they are more dependent on particular features of national contexts. Population aging, for instance, is much more of a problem in continental Europe than it is in most of the "Anglo" democracies.

The second conclusion follows from the first. There is not a single "new politics of the welfare state" but rather, quite distinct political dynamics in different "regimes" or "configurations." These regimes are characterized by different problem loads and different structures of political opportunity. As a consequence, different factors emerge as crucially important in explaining outcomes in different configura- 
tions. At the same time, there is little reason to expect much convergence in social policy outcomes across regime type.

The third conclusion is that in most countries, contemporary welfare state reform is more accurately depicted as a process of restructuring rather than dismantling. Although taking place against a backdrop of austerity, welfare state reform is not necessarily a zerosum game that simply transfers resources from political losers to political winners. In most contexts, the political logic of "middle way" solutions has proven to be compelling. In varying combinations, this restructuring involves three elements: (1) cost-containment; (2) "recommodification" or the enhancement of work incentives; and (3) "recalibration", or efforts to modify programs to fit new circumstances.

Because it is in this third claim that I think one finds the clearest implications for those studying middle-income countries, I wish to lay out the argument in more detail. The case for believing that a politics of restructuring is likely to be central turns on our sense that neither a simple defense of the status quo nor a radical dismantling of social provision is likely to prove politically feasible in most countries. Simple defense is untenable because there are indeed powerful pressures for reform. In most countries, social and economic change combined with the scale of existing commitments to force reform onto the political agenda. In Italy, to take an extreme case, projections before the commencement of reform suggested that pension commitments would consume a full $23 \%$ of Italian GDP by the year 2035. In such a context, standing pat was simply not a realistic option.

At the same time, however, welfare states continued to command extensive political protections that made radical retrenchment implausible. The widespread support for social programs reflected the huge number of direct and indirect beneficiaries (e.g., pensioners, recipients of health care). In addition, because these programs have evolved over a long period of time, there are strong path-dependent effects, involving the adaptation of many social actors to these extensive systems of social provision. This is why, for example, our research found that employers were often far more ambivalent about cutting welfare state programs than most theories of welfare state politics would have anticipated. In many countries there are also strong institutionalized protections, or veto points, that make it difficult to assemble the broad majorities required to implement far-reaching reform. Finally, the popular- ity of the welfare state means that reformers often need the support of left parties and/or unions to legitimate their efforts, and the need to garner the support or at least acquiescence of these groups generally forces reformers to accept a moderate agenda.

The combination of these extensive protections surrounding mature welfare states with major pressures for reform has facilitated a politics of negotiated adjustment in most countries. Rather than simply describing this political agenda as one of retrenchment or cost-cutting, it is useful to distinguish three components. Cost containment refers to efforts to constrain budgetary outlays, and is indeed a central (but not exclusive) part of the social agenda in most countries. It is worth emphasizing that in most contexts the chief aspiration here is to restrain future rates of growth in spending, rather than to actually reduce current outlays. Recommodification refers to efforts to enhance work incentives, or in the terminology employed by Gosta Esping-Andersen, "recommodify" labor by reducing the level of social support available to workers outside the labor market. Many analysts see this as a central aspect of the contemporary social policy agenda, and in some cases (such as Great Britain and the United States) this is accurate. But others have noted that even employers may often benefit from such social policy protections, since they encourage workers to invest in the development of particular skills. Only in the "liberal" welfare states does recommodification appear to have been central to welfare state reform.

The final dimension of reform I have termed "recalibration." The key point here is that reforms are attempting to adapt "old" welfare states to a new social and economic context. In mature welfare states program designs will often lag considerably behind social change. In some cases, recalibrating reforms emphasize program rationalization, attempting to meet traditional goals through new means (e.g., the use of market or quasi-market mechanisms) or to redesign programs that are clearly not working as they were originally intended (e.g., sickness and disability programs in much of Northern Europe). In other cases recalibration emphasizes updating programs to meet new or previously-de-emphasized goals. This can be seen most clearly in efforts to modify programs to take account of changing gender relations, patterns of household composition, and typical work histories.

Understanding that there are different dimensions of welfare state restructuring gives us a better sense of what reformers are actually 
doing, and why they are doing different things in different contexts. Different welfare states face distinctive challenges and thus shape different reform agendas. At the same time, recognizing the different dimensions of reform help us to understand how reformers are able to carry out their agendas. The multiple dimensions of reform facilitate centrist solutions in two ways. First, they facilitate bargaining as different actors trade-off different priorities. Pension reform, for instance, has often involved unusual coalitions that include those concerned with cost containment and those interested in restructuring programs to meet previously unaddressed needs (e.g., the poverty lobby in Canada; women's groups in Germany). Second, the multiple dimensions of reform allow reform to be presented as an attempt to modernize the welfare state rather than dismantle it. These possibilities provide much-needed legitimation.

I should emphasize that I am not arguing that centrist reform efforts win out everywhere, or that adjustments are necessarily adequate to the scale of the problems particular countries confront. In some countries, consensus for significant restructuring has failed to appear. In a few (e.g. New Zealand), conservative governments have launched more radical neoliberal programs with some success. But in contrast to views that emphasize either gridlock or the crumbling of social provision in the wake of globalization, our analyses emphasize the potential for processes of modest adaptation and "muddling-through".

\section{A useful comparison?}

By current standards, this is a pretty optimistic story - that is, if one believes (as I do) that extensive systems of social welfare continue to improve the quality of life for most citizens in affluent democracies. Yet one can very legitimately ask whether this account is at all relevant for thinking about the future of social policy in middle-income democracies. I will argue that in fact it is relevant, but I want to mention three important reasons for hesitancy to begin with (and readers will no doubt be able to add more of their own). In doing so, unfortunately, I must speak sweepingly of "middle-income countries." Just as one must talk about different configurations of social provision and political opportunity in discussing the affluent democracies, however, one would want to do the same here.

First, the forces of globalization are likely to have a considerably greater impact on middle- income countries than they have on the affluent democracies. The largest welfare states in the OECD world exist in countries that have long been open economies, and thus have always had to tailor their social policy profiles, at least to some extent, to the needs of international competition. By contrast, many middleincome countries have faced more substantial pressure to open up their economies and thus face greater pressure for social policy reform. At the same time, the relative power of domestic and international actors is more tilted towards the latter. One need only think about the role of international financial institutions in pressing for and shaping social policy reform to underscore this point.

Second, supporters of extensive social provision are typically much weaker in the middleincome democracies. Because welfare states are less extensive, they have smaller, less-organized constituencies. Although this varies considerably from program to program and from country to country, in general systems of social provision are less deeply embedded in domestic social arrangements. Thus the path-dependent effects that solidify support for welfare states are likely to be much more limited in these countries.

Third, in middle income countries it is not just a question of defending already developed welfare states, but of building more extensive systems of social provision. Much of our analysis of affluent democracies rests on the advantages that come to those defending welfare arrangements already in place. Building is a much more difficult political challenge than defending.

The upshot of all these points is that advocates of extensive social provision will typically be weaker, face stronger opponents, and confront a more difficult political challenge than has been true within the OECD. All this might make one question the relevance of any findings derived from the study of affluent democracies for assessing the challenges facing middle income countries.

Such a conclusion, in my view, would be too strong. Indeed, if considered flexibly and with caution, the discussion of the new politics of the welfare state in affluent democracies does have broader implications for thinking about welfare state retrenchment and restructuring. One implication is the need to consider claims about globalization's impact with a healthy dose of skepticism. Changes in the global economy are undoubtedly important, but they should not distract our attention from the relevance of domestic processes to understanding welfare 
state change - and from considering the likelihood that welfare state reforms are likely to involve quite different national responses depending on problem loads and structures of political opportunity. To take one example, many of the pension systems operating in Latin America during the 1980s clearly suffered from deep structural flaws that raised very serious questions about long-term sustainability. These systems would have eventually faced pressures to undergo major reforms even in the absence of demands emanating from the international economy. Aspects of "globalization" are not irrelevant to understanding processes of pension reform, but they are not the whole story either.

Second, one can usefully ask whether the core political logic I have outlined for most affluent democracies - what can be called the logic of the middle way - is relevant for middleincome countries. To pose the key question: Does the existing system of social provision have deep enough reservoirs of support that reformers feel compelled to negotiate with its supporters? If so, then a number of the points in the preceding analysis are likely to be of relevance.

Finally, the arguments presented above, emphasizing the need to distinguish restructuring from dismantling, can encourage us to think about broader possibilities for developing coalitions advancing multi-dimensional agendas of welfare state reform. Programs providing social benefits should not always be seen as simple transfers from one group of citizens to another - they may often provide a diverse range of benefits for different social actors. In the affluent democracies, for example, there has been a reevaluation of the role of employers in the development of the welfare state. One should not turn the conventional wisdom on its head here - it is true that strong opposition to extensions of social provision has most often been concentrated among employers. But some businesses may benefit from particular social policies - perhaps because these programs help them to obtain and retain skilled workers, or because social policies can curb “cutthroat competition" among a firm's rivals. And employers may also adapt to arrangements that have been established, making them more supportive of particular social policies over time. Thus it is worth asking whether particular programs can be constructed or redesigned in such a way that groups of employers will not oppose, or may even support, efforts to sustain social provision.

Similarly, it may be possible to assemble broader coalitions around efforts to make social programs achieve their goals more efficiently. Social programs that are badly designed, or poorly adapted to changing social conditions, may provide important opportunities for "positive-sum" bargaining involving a diverse coalition with quite distinct political interests. To take one example discussed in our edited volume, Canada has undergone a series of reforms to its old age pension system over the past fifteen years. These reforms have "clawed back" some flat-rate pension benefits from high income Canadians. The substantial budgetary savings have essentially been divided between the Treasury and an expansion of benefits for the poorest elderly. The result has been a stronger budgetary situation and an enhancement of the poverty-fighting capacity of the Canadian pension system. Indeed, the latter improved so much that by the late 1990s poverty rates among the Canadian elderly had dropped to Swedish levels - a remarkable achievement. Here, a diverse coalition, involving those interested in poverty alleviation and those focused on fiscal restraint, were able to accomplish both goals by reallocating slack resources within existing social programs.

I would not want to suggest that this happy outcome is typical - far from it. But it does suggest that the range of possibilities for creative coalition formation may be greater than often recognized. It also suggests the importance of thinking through the kinds of reforms that may appeal to a broad set of political actors.

The current climate is indeed a harsh one for systems of social provision. Yet global forces do not dictate outcomes. The multiple benefits of social programs and the multiple dimensions of possible reform may also open up opportunities for new alliances. In this context, advocates of social provision retain resources for participating in processes of restructuring and for advancing the goal of modernizing welfare systems rather than dismantling them.

Submitted on 2 May 2002

Approved on 30 August 2002 